\title{
Carbon flow in an experimental microbial ecosystem
}

\author{
Gunnar Bratbak
}

Department of Microbiology and Plant Physiology, University of Bergen, Allégaten 70, N-5000 Bergen, Norway

\begin{abstract}
The significance of the 'microbial loop' as an integral part of the marine food web is currently being discussed. We have used batch cultures to model a phytoplankton bloom and investigated carbon flow from the diatom Skeletonema costatum to bacterivorous nanoflagellates, via extracellular organic carbon (EOC) and bacteria. In the exponential growth phase, the algae did not release significant amounts of EOC (measured as amino acids and carbohydrates). After the exponential growth phase the algae released an amount of EOC that in terms of carbon equalled the amount of algal carbon biomass produced during the exponential growth phase. Although death of the algal population was related to bacterial activity, algal death did not seem to increase the amount of organic carbon available for bacterial growth. The main function of the bacteria was to convert EOC into particulate organic carbon (POC) and thereby increase the amount of POC available for bacterivores. But, as they also tied up inorganic nutrients, the bacteria prevented further growth of the algae. The main function of the bacterivorous flagellates was to remineralize both organic carbon and inorganic nutrients tied up in bacterial biomass.
\end{abstract}

\section{INTRODUCTION}

Organic carbon produced by phytoplankton in aquatic ecosystems may enter the grazing food chain via zooplankton grazing on the algal population, or it may be released as dissolved organic carbon (DOC) and enter the 'microbial loop' (Azam et al. 1983). The DOC released by the phytoplankton, called extracellular organic carbon (EOC), may be exudates released by healthy algal cells (Hellebust 1974, Fogg 1975, Mague et al. 1980), or organic material leaking out of dead or dying algal cells (Duursma 1963, Sharp 1977). DOC may also be released by zooplankton feeding on the algal population, either by loss of algal cell carbon during handling and feeding, by secretion of $\mathrm{DOC}$, or by release of DOC from feces (Lampert 1978).

The release of exudates has been shown to increase when the mineral nutrient supply becomes exhausted (Ignatiades \& Fogg 1973, Myklestad 1977, Joiris et al. 1982, Lancelot 1983, 1984). Amino acids, simple sugars, organic acids and polymers like proteins and polysaccharides are among the most common organic compounds found as exudates (Hellebust 1974). In the organic material released from dead or dying algal cells we may expect to find most of the different metabolites found in living cells. Polymers like proteins and polysaccharides may also be present.
Heterotrophic bacteria may utilize the organic material released from phytoplankton for growth (Wiebe \& Smith 1977, Wolter 1982, Jensen 1983, Brock \& Clyne 1984). Monomers and other small organic molecules can be assimilated directly, while most polymers have to be hydrolysed by exoenzymes before their monomers can be assimilated by bacteria (Somville \& Billen 1983, Somville 1984).

The bacteria will support the growth of bacterivorous flagellates (Sherr et al. 1983, Newell \& Linley 1984, Sieburth 1984, Sherr et al. 1986a), and ciliates (Berk et al. 1976, Gast \& Horstmann 1983, Lessard \& Swift 1985, Rivier et al. 1985, Sherr et al. 1986b). Grazing on the bacterial population may continue until the concentration of bacteria decrease below some threshold value where grazing becomes energetically unfavorable. This is supposed to be one of the regulatory mechanism keeping the concentration of bacteria rather constant in marine planktonic communities (Fenchel 1982, Azam et al. 1983).

Bacterivorous Protozoa and phytoplankton may both be preyed by larger predators. The organic carbon initially lost as DOC from the phytoplankton may thus re-enter the grazing food web through the microbial loop (Azam et al. 1983). Some of the carbon will however be mineralized due to respiration of the bacteria and the bacterivores. 
The chemostat has been considered a useful model ecosystem when studying steady state growth of phytoplankton (Eppley et al. 1973). Typical examples of environments where the phytoplankton may be growing at steady state may be the oligotrophic, tropical mid-ocean mixed surface layer, and the nutrientexhausted watermasses left after a bloom. In these ecosystems the phytoplankton may be limited by the rate of nutrient remineralization and their growth may be approximately balanced by zooplankton grazing.

The batch culture may be a useful experimental counterpart to the spring bloom typical of temperate and arctic ocean waters. Starting out with a medium rich in inorganic nutrients but poor in organic material, and a mixed inoculum of phytoplankton, bacteria and Protozoa, the batch culture may resemble a pre-spring bloom situation. In such an experimental set up we may expect a succession where a phytoplankton bloom is followed by a bacterial bloom. The bacterial bloom may then be followed by a bloom of bacterivorous Protozoa. A second phytoplankton bloom may possibly also be expected. By manipulating the composition of the inoculum, i.e. adding or removing one or more of the trophic levels, we can design different model food chains. Such food chains are well suited for experimental purposes when considering carbon and nutrient flow.

The aim of this study is to give a quantitative description of the carbon flow from phytoplankton to bacterivorous Protozoa, via EOC and bacteria, during an experimental bloom situation; and to give a qualitative description of the interactions between the different populations.

\section{MATERIALS AND METHODS}

Batch culture system. Three different batch cultures were run. The first was inoculated with a pure culture of Skeletonema costatum only (A-culture). The second was inoculated with $S$. costatum and with a mixed population of marine bacteria obtained by filtering a natural seawater sample through a Whatman GF/F glass fiber filter laid on top of a $1 \mu \mathrm{m}$ pore size Nuclepore filter (AB-culture). The third was inoculated with $S$ costatum and with an untreated seawater sample containing both bacteria and bacterivorous Protozoa, and all the other members of the present planktonic community (ABF-culture).

The medium, 91 in 101 carboys, was prepared from aged seawater diluted to $70 \%$ with distilled water. To remove particles the medium was filtered through a double layer of glass fiber filters (Whatman GF/C). After autoclaving, the medium was enriched with $\mathrm{NaNO}_{3}(100 \mu \mathrm{M}), \mathrm{Na}_{2} \mathrm{SiO}_{3}(20 \mu \mathrm{M})$, trace elements
(Eppley et al. 1967) and vitamins (Guillard \& Ryther 1962). Phosphate concentration of the medium was adjusted to a final concentration of about $1 \mu \mathrm{M}$ by adding appropriate amounts of a $2 \mathrm{mM}$ solution of $\mathrm{KH}_{2} \mathrm{PO}_{4}$.

Continuous lighting, $8.3 \times 10^{-2} \mu \mathrm{E} \mathrm{cm}^{-2} \mathrm{~s}^{-1}$ at the surface of the cultures, was provided by fluorescence tubes. The temperature was kept at $20^{\circ} \mathrm{C}$. Each culture was mixed with a teflon-coated magnetic stirring bar.

Biomass. Samples for counting of algae, bacteria and Protozoa were fixated with glutaraldehyde (final concentration, $0.5 \%$ ).

Living and dead algal cells were counted in a nanoplankton counting slide using a phase-contrast microscope. An algal cell was counted as dead if the protoplasm had undergone plasmolysis and the remains appeared crumpled, or when the frustule was empty; otherwise it was counted as living. Samples were stained with DAPI (Porter \& Feig 1980) and both bacteria and nanoflagellates were counted using an epifluorescence microscope. Carbon biomass of bacteria and nanoflagellates was estimated from the biovolume

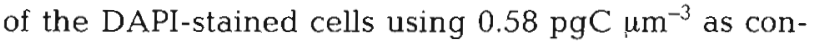
version factor for bacteria (Bratbak 1985), and $0.2 \mathrm{pgC}$ $\mu \mathrm{m}^{-3}$ as conversion factor for nanoflagellates. The conversion factor used for nanoflagellates is based on the assumption that they contain $10 \%$ carbon on a wet weight basis, and that they shrink by a factor of 2 on fixation with glutaraldehyde.

Total particulate organic carbon (POC) in the cultures was determined by filtering 10 to $50 \mathrm{ml}$ of culture onto precombusted glass fiber filters (Whatman $\mathrm{GF} / \mathrm{F}$ ) and analyzing in a CHN-analyzer (Carlo Erba Instrumentazione model 1106).

Chemical analysis. Soluble reactive phosphorus (SRP) and ammonia were measured after filtering culture samples through glass fiber filters (Whatman GF/F). SRP was measured according to Koroleff (1983), and ammonia was measured according to Strickland \& Parsons (1972).

Samples for analysis of amino acids and carbohydrates were filtered through $0.2 \mu \mathrm{m}$ pore size Nuclepore filters (Fuhrman \& Bell 1985), and stored frozen at $-80^{\circ} \mathrm{C}$ until analysis. Dissolved free amino acids (DFAA) were measured in a fluorescence spectrophotometer after fluorescence derivatization with o-phthalaldehyde (OPA) (Dawson \& Liebezeit 1983). Dissolved total amino acids (DTAA) were measured as the DFAA after acid hydrolysis (Dawson \& Liebezeit 1983). Dissolved monosaccharides ( $\mathrm{MCHO}$ ) were measured colorimetrically using the method developed by Johnson \& Sieburth (1977) as modified by Johnson et al. (1981). Dissolved total carbohydrates (TCHO) were measured after acid hydrolysis (Burney \& Sieburth 1977). 
In order to present the data on amino acids and carbohydrates in terms of carbon we have assumed that the average amino acid contained $50 \mathrm{~g}$ of carbon $\mathrm{mol}^{-1}$ (average $\mathrm{MW}=120$, average carbon content $40 \%$ (w/w) (Joiris et al. 1982), and that hexoses, containing $72 \mathrm{~g}$ of carbon $\mathrm{mol}^{-1}(\mathrm{MW}=180$, carbon content $40 \%(\mathrm{w} / \mathrm{w}))$, dominated the carbohydrates.

\section{RESULTS}

Within the first 2 to $3 \mathrm{~d}$ of the incubation the concentration of inorganic phosphate decreased below the detection limit in all 3 cultures (Fig. 1a, 2a \& 3a). Soluble reactive phosphorus (SRP) was later not detected in any of the cultures.

Ammonia was never detected in the A-culture. The concentration of ammonia in the AB-culture (Fig. 2a) increased at the same time as the bacterial biomass in the culture increased (Fig. 2b). Later, the concentration of ammonia in the AB-culture showed no constant trend. In the ABF-culture the concentration of ammonia started to increase at the same time as in the $\mathrm{AB}$-culture. However, in the ABF-culture the concentration of ammonia was continuously rising until the last week of the experiment when it was removed from
Fig. 1. Batch culture with axenic algal population (A-culture). (a) Numbers of living (LSc) and dead (DSc) Skeletonema costatum cells, and concentration of soluble reactive phosphorus (SRP). (b) Concentration of particulate organic carbon (POC). (c) Concentration of dissolved free (DFAA) and dissolved total (DTAA) amino acids, and of dissolved monosaccharides (MCHO) and dissolved total carbohydrates (TCHO)

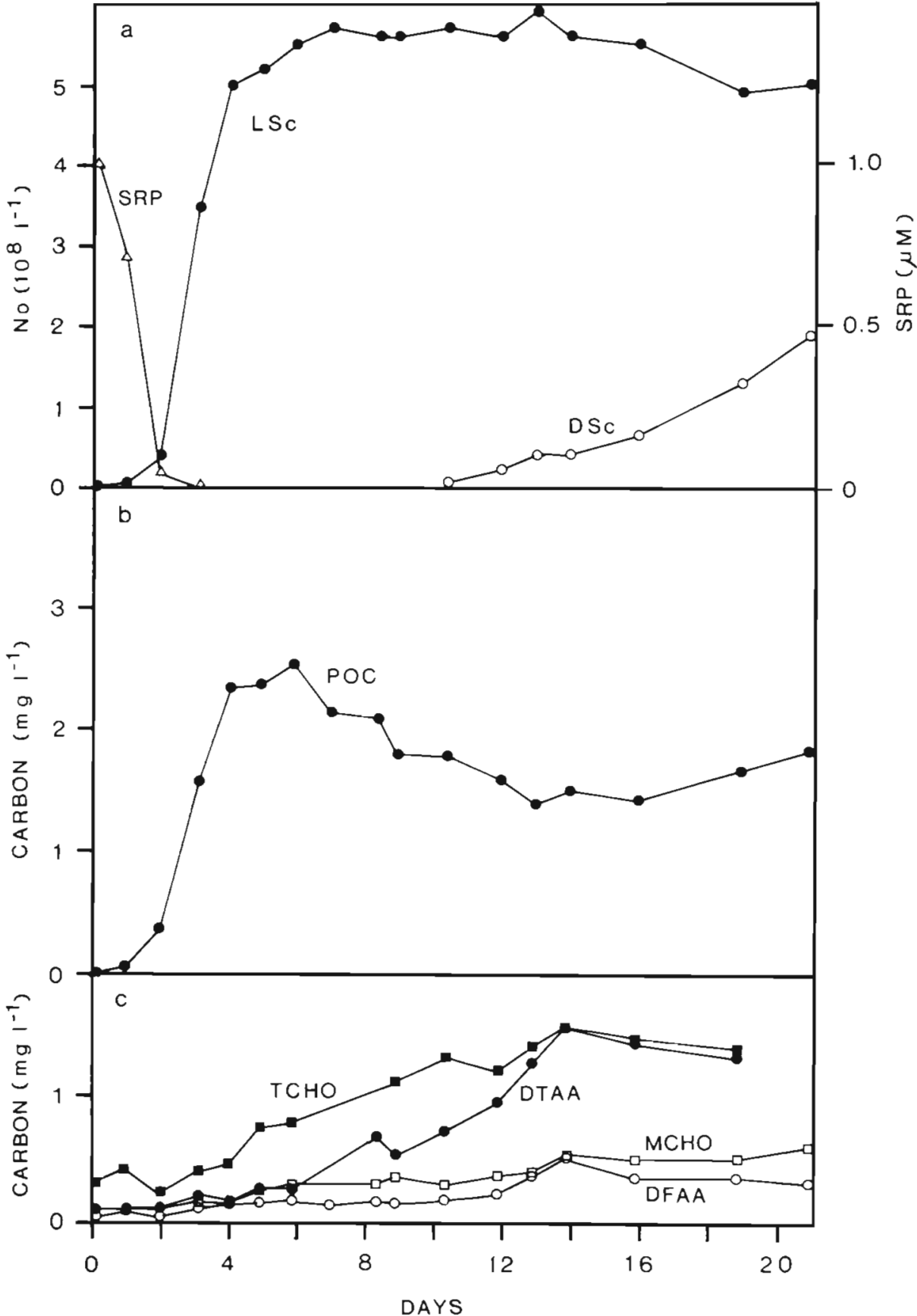


the medium by a blooming population of Chaetoceros $\mathrm{sp}$. The presence of the Chaetoceros was not intended, but obviously it must have been a member of the plankton community in the untreated seawater sample used as inoculum.

There was a significant difference in the behavior of the Skeletonema costatum populations in the 3 cultures. In the axenic algal culture (A-culture, Fig. 1a) there was a relatively high maximum algal cell number; a prolonged stationary phase; and the first dead algal cells were observed relatively late in the experiment. The 2 other cultures (AB-culture and ABFculture, Fig. 2a \& 3a) had a lowered maximum algal cell number with a short, if any, stationary phase, and the first dead algal cells were observed as early as in the log-phase period of growth. About half of the algal population remained alive in the $\mathrm{AB}$-culture after the death phase, while the whole algal population died in the ABF-culture.

Particulate organic carbon (POC) (Fig. 1b, 2b \& 3b) showed an initial increase which paralleled the logphase growth of the Skeletonema costatum population in all 3 cultures. After the log-phase growth the amount of POC decreased by about $50 \%$ in both the Aculture and the ABF-culture. This decrease in POC was in both cultures due to a decrease in the algal carbon biomass. In the $\mathrm{AB}$-culture no significant reduction in POC occurred. However, the algal carbon biomass,

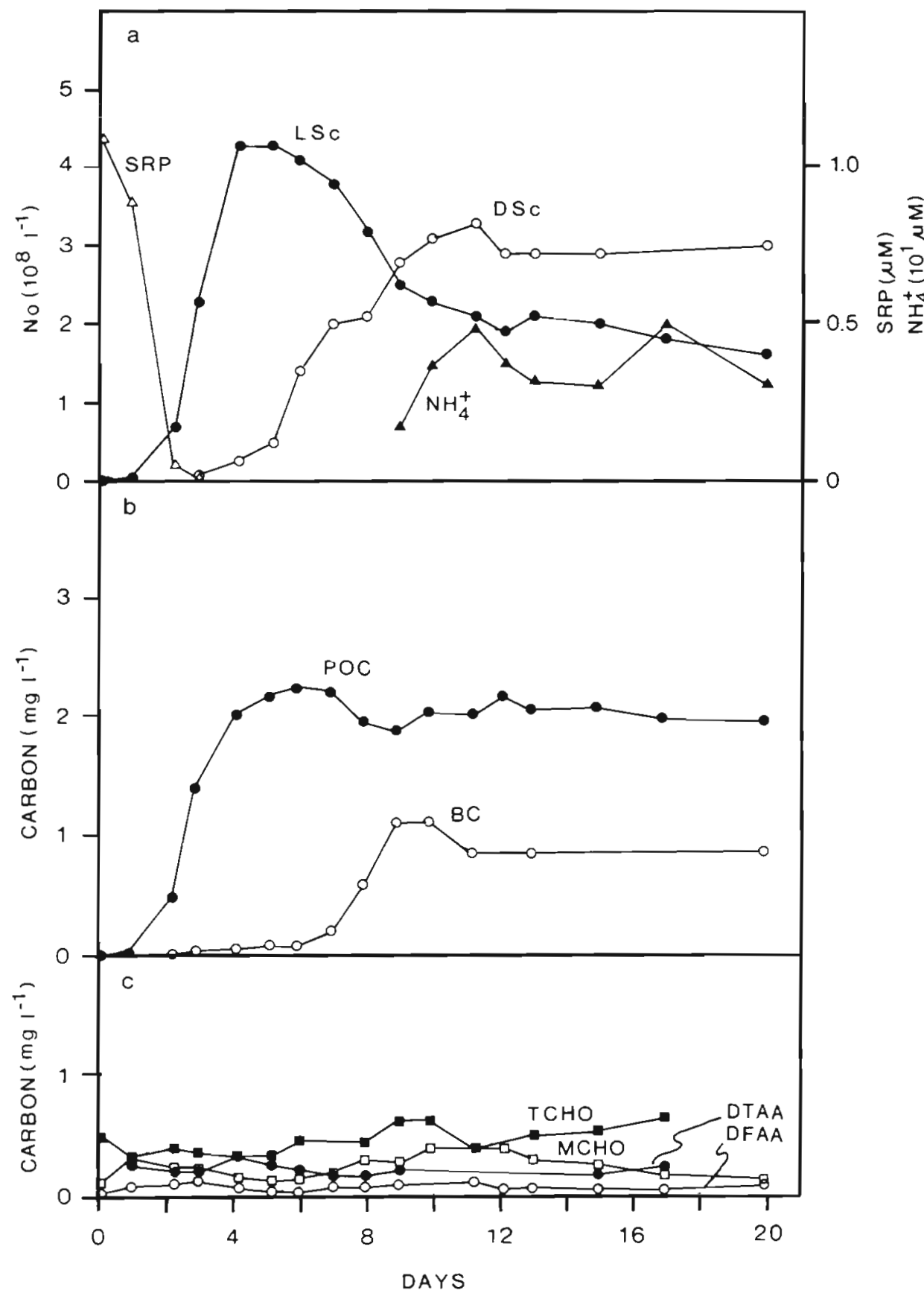

Fig. 2. Batch culture with both algae and bacteria, (AB-culture). (a) Concentration of ammonia- $N$ $\left(\mathrm{NH}_{4}{ }^{+}\right)$. (b) Concentration of bacterial carbon biomass (BC). Otherwise legends are as for Fig. 1 
which may be estimated as the difference between the POC and the bacterial carbon biomass, decreased by about the same amount as the POC and the algal carbon biomass in the 2 other cultures. In the last week of the experiment there was an increase in the amount of POC in both the A-culture and the ABF-culture. In the $\mathrm{ABF}$-culture this increase was due to the Chaetoceros sp. bloom. Both the increase in POC and the concurrent increase in total number of algal cells (living + dead) (Fig. 1a) in the A-culture indicated that the $S$. costatum population in this culture had reached a second growth phase.

The growth of the bacterial population in the $A B$ - culture (Fig. 2b) may be described as logistic. In the stationary phase the bacterial carbon biomass amounted to 40 to $50 \%$ of the POC in this culture. In the $\mathrm{ABF}$-culture however, there was a single peak value in bacterial biomass (Fig. 3b) which was followed by an increase in nanoflagellates on the next day. The average cell volumes of the fixated bacteria were in both cultures about $0.1 \mu^{3}$, and the cell volumes of the fixated flagellates were 10 to $20 \mu \mathrm{m}^{3}$. Microscopical examination showed that the flagellates lacked the red chlorophyll fluorescence typical of phototrophic organisms. We may exclude the possibility of flagellate herbivory because of the relative size

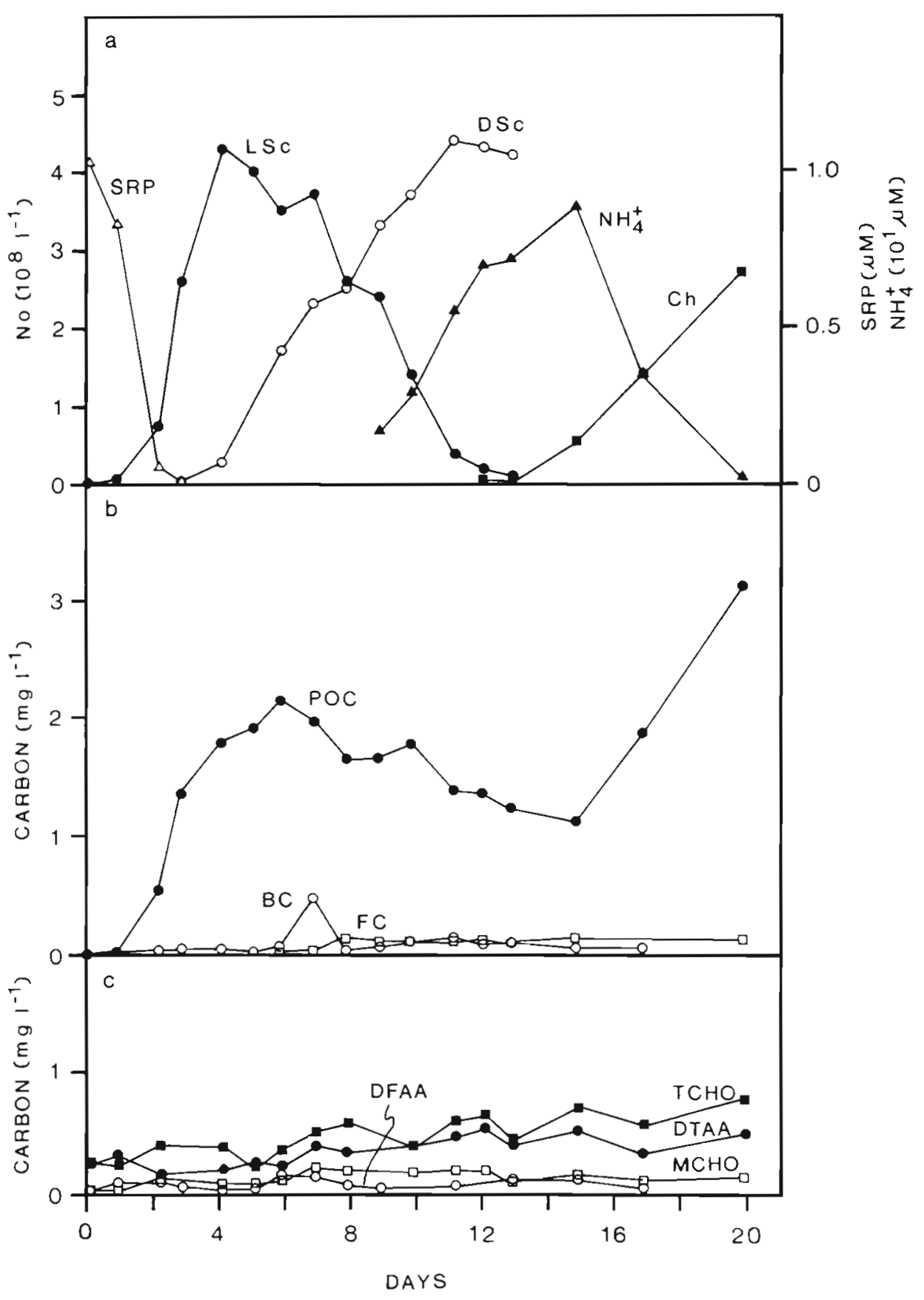

Fig. 3. Batch culture with algae, bacteria and bacterivorous nanoflagellates, (ABF-culture). (a) Number of Chaetoceros sp. (Ch). (b) Concentration of nanoflagellate carbon biomass (FC). Otherwise legends are as for Fig. 1 \& 2 
of the flagellates and the Skeletonema costatum cells. The flagellates must therefore have been bacterivorous only. The bacterial and flagellate biomasses never made up more than $10 \%$ each of the POC in the ABFculture during the second half of the experiment.

During the exponential growth phase of the Skeletonema costatum there was no significant increase in EOC (i.e. dissolved amino acids and carbohydrates) in any of the cultures (Fig. 1c, 2c \& 3c). After the exponential growth phase there was a steady increase in the concentration of both DTAA and TCHO in the A-culture (Fig. 1c). This increase was mainly due to release of combined amino acids and polysaccharides because the concurrent increase in the concentration of DFAA and of $\mathrm{MCHO}$ was low. The net increase in concentration of DTAA and of TCHO in the A-culture was $29.2 \mu \mathrm{M}\left(1.5 \mathrm{mg} \mathrm{C} \mathrm{l}^{-1}\right)$ and $16.1 \mu \mathrm{M}(1.2$ $\mathrm{mg} \mathrm{C} \mathrm{^{-1 }}$ ) respectively. The release of EOC was thus in terms of carbon about the same as the production of POC (i.e. algal carbon biomass) which was $2.6 \mathrm{mg} \mathrm{C}$ $\mathrm{l}^{-1}$. It is worth noticing that as the $S$. costatum in the Aculture entered the second growth phase (Fig. 1a, b), there was no further increase in DTAA and TCHO (Fig. 1c). This may suggest that as the algae start growing they 'turn off' the release of exudates and resume production of cell material. In the $A B$-culture and in the ABF-culture (Fig. 2c \& 3c) there were only relatively small changes in concentration of EOC.

\section{DISCUSSION}

\section{Interactions}

The difference in the behavior of the algal population can be explained by the difference in the respective bacterial activities. Bacterial uptake of phosphate (the algal growth-limiting nutrient) probably caused the reduced maximal cell numbers in both the $A B$ culture and the ABF-culture. Bacterial carbon biomass

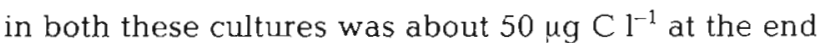
of the log phase of the algal population. With a P:C molar ratio of $2 \%$, the bacteria would contain about 0.1 umol $\mathrm{P}$ per $\mathrm{l}$ of culture, or about $10 \%$ of the total phosphate. As the bacteria can have a P:C ratio several times higher than $2 \%$ (Bratbak 1985), it seems likely that bacterial uptake of inorganic phosphate can have significantly reduced the amount of phosphorus being available for algal growth both in the $A B$-culture and in the ABF-culture. The presence of bacteria in chemostat cultures of Skeletonema costatum has also previously been found to result in lower algal cell numbers and lower algal carbon biomass than in axenic cultures of the algae (Bratbak \& Thingstad 1985).
There also seems to be a connection between algal mortality and bacterial activity. The A-culture contained no bacteria, and the algae remained viable. Both the number of living algal cells and the bacterial biomass stabilized at the same time in the AB-culture. There was in addition no further increase in concentration of ammonia as compared to the increase in ammonia in the ABF-culture. Thus, as bacterial activity ceased, a reduction in the death rate of the algal population also occurred. Bacterivory has been found to stimulate bacterial activity by releasing inorganic nutrients tied up in bacterial biomass (Fenchel \& Jørgensen 1977). This suggests that the bacterial population was active in the ABF-culture, even though the bacterial biomass was low. Bacterial activity is also indicated by the increase in concentration of ammonia. The bacteria must have been active, whether it was the bacteria growing on amino acids, or the flagellates grazing on the bacterial population, which actually released the ammonia into the medium. Thus, in this culture the bacterial activity did not cease as in the ABculture, but continued at least until the whole population of Skeletonema costatum had died.

The reason why the living Skeletonema costatum population was negatively affected by bacterial activity is not immediately obvious. Bacteria were not observed growing on or attached to living, dying or dead algal cells as observed by Albright et al. (1986). However, if the bacteria were attached to only a small fraction of the algal population, and only for a short period on each algal cell, this interaction may have escaped our attention during counting. The bacteria may also have excreted some metabolite toxic to the algal population. Because the algae ceased dying when bacterial activity ceased, the toxic metabolite could not have accumulated in the medium. Production and removal, that is consumption, decomposition, inactivation etc., must have been at equilibrium.

All nutrients, except phosphate, were added to the culture medium in excess. Phosphate was therefore the only nutrient algae and bacteria possibly were competing for. It is doubtful however, that the Skeletonema costatum population did die due to limited phosphate concentration. For $S$. costatum cells growing under phosphate limitation in batch cultures, Sakshaug \& Holm-Hansen (1977) found that 30 to $45 \%$ of the cellular phosphorus went back into the medium at the end of the exponential growth phase. This suggests that soluble organic phosphate may have been available in our cultures at the end of the $S$. costatum bloom. In the $A B$-culture there was enough bacterial biomass to bind all the phosphate in the culture. However, the death rate of the algae decreased at a time when the greatest competition for phosphate would be expected (see Fig. $2 \mathrm{a}, \mathrm{b})$. In the ABF-culture we would expect the organic 
phosphate to be mineralized by passage through the bacterial-flagellate food chain. However, SRP was not detected after the flagellate bloom. The coincidence between the disappearing of the $S$. costatum and the blooming of the Chaetoceros sp. suggests that the 2 populations in turn kept the concentration of phosphate below the detection limit. Remineralized phosphate may thus have been available to the $S$. costatum population during most of the death phase.

To be able to survive after a bloom the Skeletonema costatum, which does not form resting spores (Smetacek 1985), may physiologically adapt to nongrowth. This physiological adaption, or resting stage, may include excretion of organic material. Smetacek (1985) has argued that excretion of mucus, making the cell surface 'stickier' and promoting aggregate formation, is of survival value for senescent populations of bloom diatoms. The possibility that excreted organic matter other than mucus also may be of significance for the survival of senescent algal populations, e.g. through algal heterotrophy (Wheeler et al. 1974, White 1974, Wheeler et al. 1977), should not be excluded. Bacteria may thus have promoted algal death by breaking down excreted organic material essential for survival. This hypothesis can explain the connection between algal mortality and bacterial activity in all 3 cultures.

\section{Carbon budget}

POC was dominated by algal carbon in all 3 cultures in the first days of the experiment. The specific carbon content of the exponentially growing Skeletonema costatum cells was estimated to be $7.9 \mathrm{pg} \mathrm{C}$ cell $^{-1}$.

After the Skeletonema costatum bloom the POC in our cultures was made up by the carbon in living and dead $S$. costatum cells, and the carbon in bacteria, flagellates and Chaetoceros sp. cells. The carbon contents of the bacterial and of the flagellate populations were estimated separately. The specific carbon content of growing Chaetoceros cells in the ABF-culture was estimated from the net change in $\mathrm{POC}$ and cell number to be $9.3 \mathrm{pg} \mathrm{C}$ cell $^{-1}$, assuming the changes in the carbon content of the other populations in the culture to be insignificant.

The specific carbon content of senescent and of dead Skeletonema costatum cells may be estimated by comparing the data from the 3 different cultures. For this comparison we may use the data obtained at the end of the second week of the experiment. The cultures were then in a comparable state of development and the $S$. costatum cells appeared morphologically similar in the 3 cultures although their numbers were very different. We may thus assume that the specific carbon content of senescent $S$. costatum cells was the same in all 3 cultures and that the same was true for dead $S$. costatum cells. This enables us to make one equation for each of the 3 cultures where the carbon content of each of the populations in a culture adds up and equals the total POC content of the culture. Thus, we have 3 equations with only 2 unknowns, i.e. the specific carbon content of senescent, and the specific carbon content of dead S. costatum cells. The solution of these equations was however unique. The specific carbon content of senescent and of dead $S$. costatum cells was found to be 2.5 and $2.3 \mathrm{pg} \mathrm{C}$ cell $^{-1}$ respectively. The fact that the solution was unique suggests that the assumptions we made about the specific carbon content of the $S$. costatum cells in the 3 different cultures were justified; that our measurements are not seriously biased; and that the estimates of carbon content in the different populations are reasonably correct. It also suggests that very little organic detritus had been formed in any of the cultures.

The estimate of carbon content in the dead Skeletonema costatum cells, being about $90 \%$ of the senescent, may seem high, but it is not unreasonable. The senescent algal cells were in a generally bad condition having persisted about $10 \mathrm{~d}$ in the cultures after cessation of growth. The dead algal cells were not colonized by bacteria and showed no other sign of deterioration. If the carbon content of the cells was reduced to a minimum when the cells were living, mainly structural polymers and other refractile organic material would be left when the cells died. Any further reduction of the carbon content after the cells had died would therefore be slow. The carbon content of the senescent algal population could thus be expected to be only slightly higher than the carbon content of the newly dead algal cells.

\section{Carbon flow}

Primary production by the algae, and secondary production by the bacteria, that is, assimilation of $\mathrm{DOC}$, are the 2 processes increasing the amount of $\mathrm{POC}$ in the cultures. POC may be lost from the cultures either by the formation of DOC, or by respiration. The DOC may contain a vast number of different organic substances (Williams 1975). However, the DOC formed in the cultures was presumably mainly EOC, and therefore dominated by relatively simple organic material such as amino acids, carbohydrates, organic acids and nucleotides; and polymers of these (Hellebust 1974). As only amino acids and carbohydrates (monomers and polymers) were measured, we may have underestimated the total formation of EOC in the cultures.

While the EOC in the A-culture increased by about 
$1.8 \mathrm{mg} \mathrm{Cl}^{-1}$, there was a concurrent decrease in algal carbon biomass as represented by POC by about $1 \mathrm{mg}$ $\mathrm{Cl}^{-1}$. At least $44 \%$ of the organic material released as EOC must therefore have been produced by the algae after the exponential growth phase. The remaining amount of EOC may have leached from the algal carbon biomass. It is difficult to determine the relative importance of the 2 processes more precisely because the algae, in addition to leaching, also may have lost cell carbon due to respiration. Because of the low number of dead algal cells in the A-culture, lysis of or leaching from dead or dying algal cells could not have contributed significantly to the increase in EOC.

Assuming a growth yield of $50 \%$ (Williams 1984, Bratbak 1985), the bacterial population in the ABculture must have assimilated organic carbon equivalent to about $2.2 \mathrm{mg} \mathrm{Cl}^{-1}$ during the bacterial bloom. Algal carbon biomass, decreasing by about $1 \mathrm{mg} \mathrm{Cl}^{-1}$, could therefore not have been the only source of carbon for bacteria. The EOC in the A-culture reached a concentration $2.3 \mathrm{mg} \mathrm{Cl}^{-1}$ higher than in the $\mathrm{AB}$ culture. If the gross release of EOC in the 2 cultures was comparable and if any difference was due to bacterial assimilation of EOC, the gross release of EOC in the AB-culture would be sufficient to support the growth of the bacteria.

An apparent carbon growth yield (gross growth efficiency) of the flagellates of about $24 \%$ may be calculated from the increase in flagellate biomass and the concurrent decrease in bacterial biomass in the ABFculture. However, because it is reasonable to assume that the bacterial population was still growing, the total consumption of bacteria was probably greater than the net removal of bacterial biomass. The carbon growth yield of the flagellate population was therefore probably less than $24 \%$. Flagellate growth yields have been reported in terms of number of bacteria ingested per number of flagellates produced (Newell et al. 1981); in terms of volume (Fenchel 1982, Caron et al. 1985); and in terms of carbon biomass (Fenchel 1982). Because of large differences in the biomass per cell for both bacteria and flagellates it is difficult to compare growth yields when reported in terms of numbers. Yield in terms of carbon would be ideal for comparison, but unfortunately the use of different conversion factors and different methods for estimating carbon contents often makes comparisons confusing. To calculate yield in terms of volume requires fewer assumptions and may at present be the best unit for comparison. In terms of volume the apparent flagellate growth yield in the ABF-culture was about $70 \%$. Other workers have reported the volume growth yield to be in the range 30 to $50 \%$ (Fenchel 1982, Caron et al. 1985). This suggests that we may have overestimated the true flagellate growth yield by 40 to $130 \%$. The true carbon growth yield of the flagellates may thus have been in the order of 10 to $17 \%$ rather than $24 \%$.

Assuming the gross production of bacterial biomass in the ABF-culture to have been the same as in the ABculture (1.1 $\left.\mathrm{mg} \mathrm{Cl}^{-1}\right)$, and the growth yield of the flagellates to have been in the range 10 to $17 \%$, the gross production of flagellate biomass in the ABFculture was estimated to be 0.11 to $0.19 \mathrm{mg} \mathrm{Cl}^{-1}$. This estimate compares favorably with the net production of flagellate which was found to be about $0.12 \mathrm{mg} \mathrm{Cl}^{-1}$. Flagellates equivalent to as much as $30 \%$ of the gross flagellate biomass production may however have died and disintegrated, that is, turned into particulate detritus or DOC. Another possibility is that the flagellates may have been grazed by larger predators such as ciliates which may have been present in low numbers in the ABF-culture although they never were observed in our samples. If present, these ciliates could not have been important consumers of bacteria or algae because their food supply then would have been abundant enough to support a detectable population of ciliates. Cannibalism among the flagellates is a another possible process that can not be excluded.

Several important environmental factors were not simulated in our experiment. Diel variations in light and other abiotic factors were not used. Our medium was designed to be phosphate limited while in natural seawater several inorganic nutrients may be exhausted at about the same time. Due to a relatively high concentration of the limiting nutrient, the population densities of algae, bacteria and flagellates were higher than those commonly observed in natural environments. Introducing some or all of these abiotic factors may possibly have had a significant effect on the outcome of our experiment. Introducing biotic factors such as grazing on the algal and flagellate populations may have had a dramatic effect. However, as the main purpose of this work was to investigate qualitative and quantitative aspects of the microbial loop we designed our ecosystem as simple as possible - and even as such it was quite complex.

\section{CONCLUSIONS}

Bacterial uptake of inorganic nutrients resulted in a lower algal production during the initial algal bloom. Algal mortality after the bloom was related to bacterial activity. This interaction between algae and bacteria could not be explained by nutrient competition between the 2 populations. Bacterial uptake of organic material may have had a negative effect on the survival of the algal population after the bloom.

The amounts of POC which could be estimated from the carbon contents of the different populations pre- 
sent were in agreement with the measured amounts of POC. Thus, the estimates of carbon biomass of the different populations were reasonably correct and the formation of particulate detritus was probably low.

The carbon flow from algae to bacterivorous nanoflagellates could be described quantitatively. The production of flagellate biomass could be accounted for by the gross production of bacterial biomass, and the production of bacterial biomass could be accounted for by the gross release of EOC.

After the exponential growth phase of the algal population, the algae started to release EOC. Simultaneously there was a decrease in algal carbon biomass. Bacteria utilized EOC for growth and the organic carbon released from the algal population was recovered as bacterial carbon biomass. Bacterivorous nanoflagellates grazed the bacterial population and most of the carbon recovered as bacterial biomass was mineralized through flagellates respiration. The net effect of the microbial loop concerning net community carbon production was therefore small prior to the second algal bloom.

Bacteria tied up inorganic nutrients and prevented primary production of organic material after the initial bloom. The flagellates grazed the bacterial population and released inorganic nutrients. The main net effect of the microbial loop was thus to recycle inorganic nutrients and make a second agal bloom possible.

Acknowledgements. I thank colleagues at the Department of Microbiology and Plant Physiology, University of Bergen, for helpful discussions and for critical reading of the manuscript.

\section{LITERATURE CITED}

Albright, L. J., McCrae, S. K., May, B. E. (1986). Attached and free-floating bacterioplankton in Howe Sound, British Columbia, a coastal marine fjord embayment. Appl. environ. Microbiol. 51: 614-621

Azam, F., Fenchel, T., Field, J. G., Gray, J. S., Meyer-Reil, L. A., Thingstad, F. (1983). The ecological role of watercolumn microbes in the sea. Mar. Ecol. Prog. Ser. 10: 257-263

Berk, S. G., Colwell, R. R., Small, E. B. (1976). A study of feeding responses to bacterial prey by estuarine ciliates. Trans. Am. Micros. Soc. 95: 514-520

Bratbak, G. (1985). Bacterial biovolume and biomass estimations. Appl. environ. Microbiol. 49: 1488-1493

Bratbak, G., Thingstad, T. F. (1985). Phytoplankton-bacteria interactions: an apparent paradox? Analysis of a model system with both competition and commensalism. Mar. Ecol. Prog. Ser. 25: 23-30

Brock, T. D., Clyne, J. (1984). Significance of algal excretory products for growth of epilimnetic bacteria. Appl. environ. Microbiol. 47: 731-734

Burney, C. M., Sieburth, J. McN. (1977). Dissolved carbohydrates in seawater. II. A spectrophotometric procedure for total carbohydrate analysis and polysaccharide estimation. Mar. Chem. 5: 15-28

Caron, D. A., Goldman, J. C., Andersen, O. K. Dennett, M. R.
(1985). Nutrient cycling in a microflagellate food chain. II. Population dynamics and carbon cycling. Mar. Ecol. Prog. Ser. 24: 243-254

Dawson, R., Liebezeit, G. (1983). Determination of amino acids and carbohydrates. In: Grasshoff, K., Ehrhardt, M., Kremling, K. (ed.) Methods of seawater analysis, 2 nd edn. Verlag Chemie, Weinheim, New York

Duursma, E. K. (1963). The production of dissolved organic matter in the sea, as related to the primary gross production of organic matter. Neth. J. Sea Res. 2: 85-94

Eppley, R. W., Holms, R. W., Strickland, J. D. H. (1967). Sinking rates of marine phytoplankton measured with a fluorometer. J. exp. mar Biol. Ecol. 1: 191-208

Eppley, R. W., Renger, R. H., Venrick, E. L., Mullin, M. M. (1973). A study of plankton dynamics and nutrient cycling in the central gyre of the North Pacific Ocean. Limnol. Oceanogr. 18: 534-551

Fenchel, T. (1982). Ecology of heterotrophic microflagellates, II. Bioenergetics and growth. Mar. Ecol. Prog. Ser. 8: 225-231

Fenchel, T. M., Jørgensen, B. B. (1977). Detritus food chains of aquatic ecosystems: the role of bacteria. In: Alexander, $M$. (ed.) Advances in microbial ecology, Vol. 1. Plenum Press, New York, p. 1-58

Fogg, G. E. (1975). Primary productivity. In: Riley, J. P., Skirrow, G. (ed.) Chemical oceanography, Vol 2., 2nd edn. Academic Press, London, p. 385-453

Fuhrman, J. A., Bell, T. M. (1985). Biological considerations in the measurement of dissolved free amino acids in seawater and implications for chemical and microbiological studies. Mar. Ecol. Prog. Ser. 25: 13-21

Gast, V., Horstmann, U. (1983). N-remineralization of phytoand bacterioplankton by the marine ciliate Euplotes vannus. Mar. Ecol. Prog. Ser. 13: 55-60

Guillard, R. R. L., Ryther, J. H. (1962). Studies of marine planktonic diatoms. I. Cyclotella nana Hustedt and Detonula confervacea (Cleve) Gran. Can. J. Microbiol. 8: 229-239

Hellebust, J. A. (1974). Extracellular products. Bot. Monogr. 10: 838-863

Ignatiades, L., Fogg, G. E. (1973). Studies on the factors affecting the release of organic matter by Skeletonema costatum (Greville) Cleve in Culture. J. mar, biol. Ass. U. K. 53: $937-956$

Jensen, L. M. (1983). Phytoplankton release of extracellular organic carbon, molecular weight composition, and bacterial assimilation. Mar. Ecol. Prog. Ser. 11: 39-48

Johnson, K. M., Sieburth, J. McN. (1977). Dissolved carbohydrates in seawater. I. A precise spectrophotometric analysis for monosaccharides. Mar. Chem. 5: 1-13

Johnson, K. M., Burney, C. M., Sieburth, J. McN. (1981). Doubling the production and precision ot the MBTH spectrophotometric assay for dissolved carbohydrates in seawater. Mar. Chem. 10: 467-473

Joiris, C., Billen, G., Lancelot, C., Daro, M. H., Mommaerts, J. P., Bertels, A., Bossicart, M., Nijs, J., Hecq, J. H. (1982). A budget of carbon cycling in the Belgian coastal zone. Relative roles of zooplankton, bacterioplankton and benthos in the utilization of primary production. Neth. J. Sea Res. 16: 260-275

Koroleff, F. (1983). Determination of phosphorus. In: Grasshoff, K., Ehrhardt, M., Kremling, K. (ed.) Methods of seawater analysis, 2nd edn. Verlag Chemie, Weinheim, New York, p. 125-139

Lampert, W. (1978). Release of dissolved organic carbon by grazing zooplankton. Limnol. Oceanogr. 23: 831-834

Lancelot, C. (1983). Factors affecting phytoplankton 
extracellular release in the Southern Bight of the North Sea. Mar. Ecol. Prog. Ser. 12: 115-121

Lancelot, C. (1984). Metabolic changes in Phaeosystis poucheti (Hariot) Lagerhein during the spring bloom in Belgian coastal waters. Estuar. coast. Shelf Sci. 18: 593-600

Lessard, E. J., Swift, E. (1985). Species-specific grazing rates of heterotrophic dinoflagellates in oceanic waters, measured with a dual-label radioisotope technique. Mar. Biol. 87: 289-296

Mague, T. H., Friberg, E., Hughes, D. J., Morris, 1. (1980). Extracellular release of carbon by marine phytoplankton, a physiological approach. Limnol. Oceanogr. 25: 262-279

Myklestad, S. (1977). Production of carbohydrates by marine phytoplankton diatoms. II. Influence of the N/P ratio in the growth medium on the assimilation ratio, growth rate, and production of cellular and extracellular carbohydrates by Chaetoceros affinis var. Willei (Gran) Hustedt and Skeletonema costatum (Grev.) Cleve. J. exp. mar. Biol. Ecol. 29: 161-179

Newell, R. C., Linley, E. A. S. (1984). Significance of microheterotrophs in the decomposition of phytoplankton: estimates of carbon and nitrogen flow based on the biomass of plankton communities. Mar. Ecol. Prog. Ser. 16: 105-119

Newell, R. C., Lucas, M. I., Linley, E. A. S. (1981). Rate of degradation and efficiency of conversion of phytoplankton debris by marine micro-organisms. Mar. Ecol. Prog. Ser. 6 : $123-136$

Porter, K. G., Feig, Y. S. (1980). The use of DAPI for identifying and counting aquatic microflora. Limnol. Oceanogr. 25: 943-948

Rivier, A., Brownlee, D. C., Sheldon, R. W., Rassoulzadegan, F. (1985). Growth of microzooplankton: a comparative study of bactivorous zooflagellates and ciliates. Mar. Microb. Food Webs 1: $51-60$

Sakshaug, E., Holm-Hansen, O. (1977). Chemical composition of Skeletonema costatum (Grev.) Cleve and Pavlova (Monochrysis) lutheri (Droop) Green as a function of nitrate-, phosphate-, and iron-limited growth. J. exp. mar. Biol. Ecol. 29: 1-34

Sharp, J. H. (1977). Excretion of organic matter by marine phytoplankton: do healthy cells do it? Limnol. Oceanogr. 22: 381-399

Sherr, B. F., Sherr, E. B., Berman, T. (1983). Grazing, growth, and ammonium excretion rates of a heterotrophic microflagellate fed with four species of bacteria. Appl environ. Microbiol. 45: 1196-1201
Sherr, B. F., Sherr, E. B., Andrew, T. L., Fallon, R. D., Newell, S. Y. (1986a). Trophic interactions between heterotrophic protozoa and bacterioplankton in estuarine water analyzed with selective metabolic inhibitors. Mar. Ecol. Prog. Ser. 32: 169-179

Sherr, B. F., Sherr, E. B., Fallon, R. D., Newell, S. Y. (1986b). Small, aloricate ciliates as a major component of the marine heterotrophic nanoplankton. Limnol. Oceanogr. 31: $177-183$

Sieburth., J. McN. (1984). Protozoan bacterivory in pelagic marine waters. In: Hobbie J. E., Williams, P. J. (ed.) Heterotrophic activity in the sea. NATO conference series. Plenum Press, New York, p. 405-444

Smetacek, V. S. (1985). Role of sinking in diatom life-history cycles: ecological, evolutionary and geological significance. Mar. Biol. 84: 239-251

Somville, M. (1984). Measurement and study of substrate specificity of exoglucosidase activity in eutrophic water. Appl. environ. Microbiol. 48: 1181-1185

Somville, M., Billen, G. (1983). A method for determining exoproteolytic activity in natural waters. Limnol. Oceanogr. 28: 190-193

Strickland, J. D. H., Parsons, T. R. (1972). A practical handbook of seawater analysis, 2nd edn. Bull. Fish. Res. Bd Can. 167

Wheeler, P. A., North, B. B., Stephens, G. C. (1974). Amino acid uptake by marine phytoplankters. Limnol. Oceanogr. 19: 249-259

Wheeler, P., North, B., Littler, M., Stephens, G. (1977). Uptake of glycine by natural phytoplankton communities. Limnol. Oceanogr. 22: 900-910

White, A. W. (1974). Growth of two facultatively heterotrophic marine centric diatoms. J. Phycol. 10: 292-300

Wiebe, W. J., Smith, D. F. (1977). Direct measurement of dissolved organic carbon release by phytoplankton and incorporation by microheterotrophs. Mar. Biol. 42: 213-223

Williams, P. J. leB. (1975). Biological and chemical aspects of dissolved organic material in sea water. In: Riley, J. P., Skirrow, G. (ed.) Chemical oceanography, Vol 2, 2nd edn. Academic Press, London, p. 301-363

Williams, P. J. leB. (1984). Bacterial production in the marine food chain: the emperor's new suit of clothes? In: Fasham, M. J. R. (ed.) Flows of energy and matter in marine ecosystems; theory and practice. NATO conference series. Plenum Press, New York, p. 271-299

Wolter, K. (1982). Bacterial incorporation of organic substances released by natural phytoplankton populations. Mar. Biol. Prog. Ser. 7: 287-295 